\title{
Plants and Lactic Acid Bacteria Combination for New Antimicrobial and Antioxidant Properties Product Development in a Sustainable Manner
}

\author{
Elena Bartkiene ${ }^{1,2, *(D)}$, Vita Lele ${ }^{1,2}$, Vytaute Starkute ${ }^{1,2}$, Paulina Zavistanaviciute ${ }^{1,2}$, \\ Egle Zokaityte ${ }^{1}$, Ieva Varinauskaite ${ }^{1}$, Greta Pileckaite ${ }^{1}$, Laura Paskeviciute ${ }^{1}$, \\ Gintare Rutkauskaite ${ }^{1}$, Tomas Kanaporis ${ }^{1}$, Laura Dmitrijeva ${ }^{1}$, Pranas Viskelis ${ }^{3}$, \\ Antonello Santini ${ }^{4, *(D)}$ and Modestas Ruzauskas ${ }^{5,6}$ (D)
}

1 Department of Food Safety and Quality, Faculty of Veterinary, Lithuanian University of Health Sciences, Mickeviciaus str. 9, LT-44307 Kaunas, Lithuania; vita.lele@lsmuni.lt (V.L.); vytaute.starkute@lsmuni.lt (V.S.); paulina.zavistanaviciute@lsmuni.lt (P.Z.); egle.zokaityte@lsmuni.lt (E.Z.); ieva.varinauskaite@stud.lsmu.lt (I.V.); greta.pileckaite@stud.lsmu.lt (G.P.); laura.paskeviciute@stud.lsmu.lt (L.P.); gintare.rutkauskaite@lsmuni.lt (G.R.); tomas.kanaporis@stud.lsmu.lt (T.K.); laura.dmitrijeva@stud.lsmu.lt (L.D.)

2 Institute of Animal Rearing Technologies, Faculty of Animal Sciences, Lithuanian University of Health Sciences, Mickeviciaus str. 9, LT-44307 Kaunas, Lithuania

3 Institute of Horticulture, Lithuanian Research Centre for Agriculture and Forestry, Kauno str. 30, LT-54333 Babtai, Lithuania; biochem@1sdi.lt

4 Department of Pharmacy, University of Napoli Federico II, Via D. Montesano 49, 80131 Napoli, Italy

5 Institute of Microbiology and Virology, Faculty of Veterinary, Lithuanian University of Health Sciences, Mickeviciaus str. 9, LT-44307 Kaunas, Lithuania; modestas.ruzauskas@lsmuni.lt

6 Department of Anatomy and Physiology, Faculty of Veterinary, Lithuanian University of Health Sciences, Mickeviciaus str. 9, LT-44307 Kaunas, Lithuania

* Correspondence: elena.bartkiene@lsmuni.lt (E.B.); asantini@unina.it (A.S.); Tel.: +37-060135837 (E.B.); $+39-812539317$ (A.S.)

\begin{abstract}
In this study, nutraceuticals based on antimicrobial ingredients (Artemisia absinthium water extract and essential oil (EO), Lactobacillus uvarum LUHS245 strain cultivated in a whey media, and blackcurrants juice (BCJ) preparation by-products were developed. In addition, two texture forming agents for nutraceutical preparations were tested (gelatin and agar). The developed nutraceutical ingredients showed antimicrobial properties: Artemisia absinthium EO (concentration 0.1\%) inhibited methicillin-resistant Staphylococcus aureus, Enterococcus faecium, Bacillus cereus, Streptococcus mutans, Staphylococcus epidermidis, and Pasteurella multocida; LUHS245 strain inhibited 14 from the 15 tested pathogenic strains; and $\mathrm{BCP}$ inhibited 13 from the 15 tested pathogenic strains. The best formulation consisted of the Artemisia absinthium EO, LUHS245, and BCP immobilised in agar and this formulation showed higher TPC content (by $2.1 \%$ higher), as well as higher overall acceptability (by $17.7 \%$ higher), compared with the formulation prepared using gelatin.
\end{abstract}

Keywords: nutraceuticals; by-products; antimicrobial ingredients; essential oil; lactic acid bacteria; blackcurrants

\section{Introduction}

The global nutraceutical market has grown in the last few years and this growth is expected to continue. For this reason, the challenges related to high prices for nutraceutical compounds became very real [1]. One of the solutions to reduce prices, as well as ensure sustainability of the nutraceuticals 
preparation, is the valorization of the food processing industry by-products by recovering the functional compounds to be used for nutraceuticals preparation. Nowadays, industrial principles and sustainable innovations aiming at fully recycling by-products (BY), in which BY are used as raw materials for developing new ingredients and products, became very important [2-6]. The large amount of functional and bioactive materials loss in the BY that are usually treated as waste to dispose of and, in addition, the disposal of the food industry BY generates serious concerns regarding management, economic, and environmental problems [2]. Nonetheless, many of these BY can be valorized into other production systems, e.g. nutraceuticals preparation [3-8].

Cheese whey is a good example of a dairy industry BY that can be used and given high added value in nutraceutical formulations. Many treatments (biological, physicochemical, direct land application, thermal, precipitation, flocculation, acid precipitation, electrochemical, and membrane technologies) have been suggested for whey valorisation [9]. Nonetheless, roughly $50 \%$ of whey goes to disposal since it is not processed or valorized [10]. The main challenge to face in whey valorization is its components concentration [11]. From this point of view, very high value functional compounds could be projected to valorize whey substrate in an economical way. Whey retains up to $55 \%$ compounds from milk, however its composition is not stable and is varied; but, the beneficial characteristics of whey could be applied in food/nutraceuticals/feed industries [12]. At the same time, whey can be used to increase functional microorganisms viability during storage [13-15].

Other high quantities of the food industry BY are produced by juice preparation, and these BY are not enough and efficiently valorized. Today, consumers are interested in higher value foods, besides possessing sensory attractiveness and nutrients, to have health-promoting characteristics. It was published that a diet rich in berries/fruits positively affects human health, as well as regular consumption of berries/fruits may delay ageing processes and reduce the risk of various diseases [16-18]. Berry fruits have been identified as important sources of gallic and ellagic acid, as well as flavonoids, tannins, stilbenoids, and phenolic acids [16]. Also, berry and fruits polyphenols may act as antimicrobial agents for a wide range of pathogens [19]. Blackcurrants contain desirable phytochemicals, which possess antioxidant properties [20]. Blackcurrants polyphenols possess preventive and therapeutic effects [21], but a very high content of these valuable compounds are lost because they remain in the BY.

Also, adoption as active substances sources from non conventionally used plants, such as A. absinthium, which is well known in traditional medicine, is nowadays becoming very popular. The Artemisia essential oils (EOs) contained high concentrations of myrcene, trans-thujone, and trans-sabinyl acetate. Abovementioned compounds inhibite Candida albicans, Staphylococcus aureus, Trichophyton rubrum, Microsporum canis, Cryptococcus neoformans, Microsporum gypseum, Escherichia coli, Staphylococcus epidermidis, Fonsecaea pedrosoi, and Aspergillus niger [22].

The end point of the proposed work was based on the fact that high value products preparation can be realised in a sustainable manner by using food industry BY valorization. In this experiment, nutraceuticals in chewing tablets form, based on antimicrobial ingredients (Artemisia absinthium extracts, Lactobacillus uvarum LUHS245 strain, and blackcurrants juice preparation BY), were developed. In addition, two texture forming agents for nutraceutical preparations were tested (agar and gelatin) and the best formulations according to quality parameters (color coordinates, texture, total phenolic compounds content, antioxidant activity, as well as sensory properties) were selected.

\section{Materials and Methods}

\subsection{Materials Used for Nutraceuticals Preparation}

Artemisia absinthium essential oil (EO) was purchased from the Institute of Aromatherapy (Kaunas, Lithuania). Artemisia absinthium dried plant (underground part) was obtained from the local pharmaceutical company "Camelia" (Kaunas, Lithuania). The water extract was prepared by mixing $40.00 \mathrm{~g}$ of Artemisia absinthium dried plant with $1260 \mathrm{~mL}$ of boiled water $\left(98 \pm 2{ }^{\circ} \mathrm{C}\right.$ temperature). After $30 \mathrm{~min}$, the plant and water mixture was filtered through a gauze filter and used for antimicrobial 
analysis. Blackcurrants (Ribes nigrum, variety "Ben Alder") BY were obtained from the Institute of Horticulture, Lithuanian Research Centre for Agriculture and Forestry (Babtai, Kaunas distr., Lithuania) in 2018. Blackcurrants BY were dried by lyophilization (at $-40 \pm 2{ }^{\circ} \mathrm{C}$ ). For lyophilization, a sublimator $3 \times 4 \times 5$ (ZIRBUS Technology $\mathrm{GmbH}$, Germany) was used. The condenser temperature was $-85^{\circ} \mathrm{C}$ and the vacuum was $2 \times 10^{-6} \mathrm{MPa}$. The samples were frozen at $-40 \pm 2{ }^{\circ} \mathrm{C}$ in a laboratory freezer and then left in a freeze dryer for $72 \mathrm{~h}$. Whey (lactose $4.0 \%$, protein $0.8 \%$, lactic acid $0.5 \%$, pH value 4.45 , titratable acidity 0.22 , minerals $0.6 \%$, total solids $6.5 \%$ ) was purchased from JSC "Pieno zvaigzdes" (Kaunas, Lithuania) and used as a media for a Lactobacillus uvarum LUHS245 strain biomass growth. The experiment used LAB strain Lactobacillus uvarum LUHS245, which previously demonstrated good antimicrobial activities against a variety of pathogenic and opportunistic microorganisms, which was provided by Lithuanian University of Health Sciences collection (Kaunas, Lithuania). The LUHS245 strain was stored at $-80{ }^{\circ} \mathrm{C}$ in a Microbank system (Pro-Lab Diagnostics, Birkenhead, UK) and grown in MRS broth (CM 0359, Oxoid, Hampshire, UK) at $30{ }^{\circ} \mathrm{C}$ for $48 \mathrm{~h}$ prior to use. The agar powder (Gelidium sesquipedale algae, Rapunzel, Germany) was used as a polymer with mucoadhesive properties for nutraceuticals forming. In addition, gelatin was also tested (Klingai, Lithuania).

\subsection{Grown of the Lactobacillus uvarum LUHS245 in Whey Media}

For Lactobacillus uvarum LUHS245 biomass growth, whey media was used and for growth parameters optimisation glucose (GLU), yeast extract $(\mathrm{Y})$ and saccharose (SA) additives were tested. Prior to fermentation, the whey was sterilised, cooled to $30{ }^{\circ} \mathrm{C}$, and different concentrations of Y, GLU, and SA $(0.5 ; 1.0 ; 1.5 ; 2.0 ; 2.5 ; 3.0 ; 3.5 ; 4.0 ; 4.5 ; 5.0 \%)$ were added, with the purpose of improving the growth of the LUHS245. The optimal quantities of the Y, GLU, and SA, as well as the optimal fermentation time (the LAB count in the whey media was analysed every $3 \mathrm{~h}$ ), were selected. Lyophilisation of the LUHS245 cultivated in the dairy production BY was performed in a sublimator $3 \times 4 \times 5$ (ZIRBUS Technology GmbH, Harz, Germany). The parameters of the process were the same as described for blackcurrants BY lyophilisation. The LAB count in the lyophilised powder was determined.

\subsection{Lactic Acid Bacteria Count in Fermented Lyophilised Dairy Production By-Products Media}

The lactic acid bacteria (LAB) count in fermented lyophilised dairy production BY was evaluated according to ISO 15214:1998 [23]. The petri plates, with sterile MRS agar (CM0361, Oxoid) of $5 \mathrm{~mm}$ of thickness, were separately seeded with the LAB diluted suspension using sowing in surface and were incubated under anaerobic conditions at $30^{\circ} \mathrm{C}$ for $72 \mathrm{~h}$. The number of LAB colonies on the surface of the MRS agar plate was calculated and expressed as $\log _{10}$ of colony forming units per gram (CFU g $\left.{ }^{-1}\right)$.

2.4. Antimicrobial Activity of the Artemisia Absinthium Water Extract and Essential Oil, Lactobacillus uvarum LUHS245, and Blackcurrants By-Products Evaluation

Antimicrobial activity of the Artemisia absinthium water extract and essential oil (EO), Lactobacillus uvarum LUHS245, and blackcurrants BY against Klebsiella pneumoniae, Salmonella enterica, Pseudomonas aeruginosa, Acinetobacter baumanni, Proteus mirabilis, methicillin-resistant Staphylococcus aureus (MRSA), Enterococcus faecalis, Enterococcus faecium, Bacillus cereus, Streptococcus mutans, Enterobacter cloacae, Citrobacter freundii, Staphylococcus epidermidis, Staphylococcus haemolyticus, Pasteurella multocida was assessed by measuring the diameters of inhibition zones (DIZ, $\mathrm{mm}$ ) in agar well diffusion assays. The abovementioned method was described in detail by Bartkiene et al. [24].

LUHS245 was grown in de Man Rogosa Sharpe (MRS) medium (Biolife, Milan, Italy) at $30^{\circ} \mathrm{C}$. Two percent of the MRS solution $(v / v)$, in which the strain was cultured, were inoculated into fresh medium and propagated for $18 \mathrm{~h}$. The cells were harvested by centrifugation $\left(6000 \times g, 10 \mathrm{~min}, 4{ }^{\circ} \mathrm{C}\right)$. The culture supernatant was filtered through a $0.2 \mathrm{~mm}$ sterile Millipore filter (Merck KGaA, Darmstadt, Germany) to remove all cells and adjusted to $\mathrm{pH} 6.5$ with $5 \mathrm{~mol} \mathrm{~L}^{-1} \mathrm{NaOH}$ to eliminate the organic acids effect. Supernatants were used for the determination of the antimicrobial activities of LUHS245 
strain against a variety of pathogenic and opportunistic bacterial strains. Agar well diffusion assay was used for the antimicrobial activities testing of the Artemisia absinthium water extract, LUHS245, and blackcurrants juice preparation by-products. For this purpose, $0.5 \mathrm{McFarland}$ Unit density suspension of each pathogenic bacteria strain was inoculated onto the surface of cooled Mueller Hinton Agar (Oxoid, UK) using sterile cotton swabs. Wells of $6 \mathrm{~mm}$ in diameter were punched in agar and filled with $50 \mu \mathrm{L}$ of the tested compounds. The antimicrobial activities against the tested bacteria were determined by measuring the diameter of the inhibition zones $(\mathrm{mm})$. The experiments were repeated three times and the average of the inhibition zones was calculated.

In addition, the antimicrobial activity of the Artemisia absinthium water extracts and EO against the abovementioned pathogenic and opportunistic strains were determined in liquid media [25]. Antimicrobial activity was defined as the Artemisia absinthium water extract (10\%, 20\%, and 30\% concentrations $)$ and/or EO ( $0.1 \%$ concentration) inhibiting visible microbial growth. For this purpose, water extracts and EO were placed into $1 \mathrm{~mL}$ of Mueller Hinton Broth (Oxoid, UK). Then, $10 \mu \mathrm{L}$ of 0.5 McFarland density of the pathogenic and opportunistic bacterial strain, initially cultivated on Mueller Hinton Agar (Oxoid, UK), was added, mixed, and incubated at $35^{\circ} \mathrm{C}$ for $24 \mathrm{~h}$. After incubation, the viable pathogenic and opportunistic bacterial strains were controlled by plating them on an appropriate universal medium (Tryptic Soy Agar, Oxoid). The results were interpreted as (-) if the pathogens did not grow on universal medium and $(+)$ if the pathogens grew on universal medium. Growth control without extracts and EO was carried out.

Experiments were performed in triplicate.

\subsection{Nutraceuticals Formulation}

The main ingredients, formulations, and technological steps of the separate layers of the nutraceuticals based on Artemisia absinthium EO, Lactobacillus uvarum LUHS245 cultivated in a whey media, and blackcurrant juice preparation BY, as well as the whole nutraceutical-product, are shown in Scheme 1. Two formulations of the three layer nutraceuticals based on agar and gelatin were prepared.

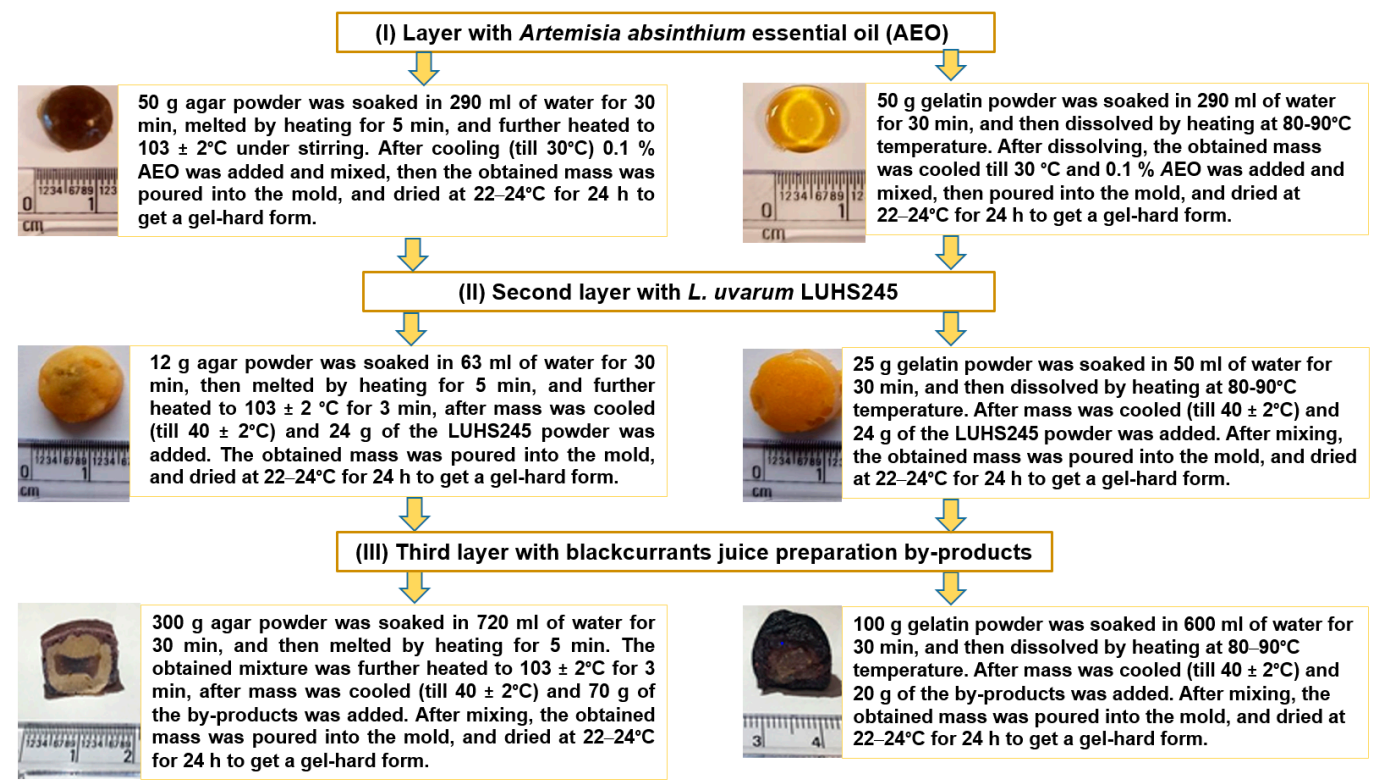

Scheme 1. The main ingredients and formulation of the separate layer of the nutraceutical based on Artemisia absinthium EO, Lactobacillus uvarum LUHS245 cultivated in whey substrate, and blackcurrant juice preparation by-products. 
2.6. The Evaluation of Total Phenolic Compounds (TPC) Content in Separate Layers and the Whole Formulation of the Prepared Nutraceuticals and Their Antioxidant Activity

The TPC content in separate layers and the whole formulation of the prepared nutraceuticals was determined by the spectrophotometric method, as reported elsewhere [26]. The absorbance of samples was measured at $765 \mathrm{~nm}$ using spectrophotometer J.P. SELECTA S.A. V-1100D (Barcelona, Spain). Antioxidant activity of the separate layers and the whole formulation of the prepared nutraceuticals was evaluated according to the method reported by Zhu et al. [27].

\subsection{Evaluation of Nutraceuticals Colour Coordinates, Texture, and Overall Acceptability}

The color characteristics were evaluated using a CIE $L * a * b *(L *=$ lightness; $a *=$ redness or $-a *=$ greenness; $b *=$ yellowness or $-b *=$ blueness) system (CromaMeter CR-400, Konica Minolta, Japan). The hardness parameter was evaluated using a Brookfield texture analyser (Middleboro, MA, USA). Samples were compressed to $10 \%$ of their original height at a crosshead speed of $10 \mathrm{~mm} / \mathrm{s}$. The resulting peak force of compression was reported as nutraceutical hardness. Three replicates from three different sets of preparation were analyzed and averaged. The overall acceptability was carried out by 50 judges according to International Standards Organisation 8586-1 method [28], using a $140 \mathrm{~mm}$ hedonic line scale, ranging from 140 (extremely like) to 0 (extremely dislike).

\subsection{Statistical Analysis}

Statistical analysis was performed using multivariate analysis of variance (ANOVA). For data processing, software packages STATISTICA 7.1 (StatSoft Inc., Tulsa, USA) and SPSS 20.0 (IBM Corp., Armonk, NY, USA) were used. Statistical significance was set at $p \leq 0.05$.

\section{Results and Discussion}

3.1. Antimicrobial Properties of the Artemisia Absinthium Water Extract and Essential Oil (EO), Lactobacillus uvarum LUHS245, and Blackcurrant Juice Preparation By-Products

Inhibition of the growth of pathogenic bacteria by Artemisia absinthium water extract, L. uvarum LUHS245, and blackcurrant juice preparation BY is shown in Table 1. Artemisia absinthium water extract showed antimicrobial activity against Pasteurella multocida $(20.4 \pm 4.1 \mathrm{~mm})$. Lactobacillus uvarum LUHS245 strain inhibited 14 from the 15 tested pathogenic strains, and the highest inhibition zones against Pasteurella multocida and Bacillus cereus 1801 were found $(22.0 \pm 0.2$ and $21.5 \pm 0.3 \mathrm{~mm}$, respectively). Blackcurrant juice preparation BY inhibited 13 from the 15 tested pathogenic strains, and the highest inhibition zones against Pasteurella multocida, Bacillus cereus 18 01, and Streptococcus mutans were found $(30.7 \pm 0.5,21.4 \pm 0.2$, and $20.1 \pm 0.1 \mathrm{~mm}$, respectively). According to the results obtained, preparation of the nutraceuticals outer layer by using blackcurrant juice preparation BY can be very promising as a dental caries prophylaxis because antimicrobial activity against Streptococcus mutans was established. Streptococcus mutans can cause dental caries and it has been reported that more than $90 \%$ of the population is suffering from it [29].

Antimicrobial activities of the Artemisia absinthium EO (concentration $0.1 \%$ ) and Artemisia absinthium water extract (concentrations 10\%, 20\%, and 30\%) against pathogenic opportunistic microorganisms in liquid medium are shown in Table 2. Artemisia absinthium water extract does not inhibit pathogenic opportunistic microorganisms in liquid medium, however Artemisia absinthium EO (concentration $0.1 \%$ ) inhibited methicillin-resistant Staphylococcus aureus M87fox, Enterococcus faecium 103, Bacillus cereus 18 01, Streptococcus mutans, Staphylococcus epidermidis, and Pasteurella multocida. According to the results obtained, for nutraceuticals preparation, Artemisia absinthium EO was selected. 
Table 1. Inhibition of the growth of pathogenic bacteria by Artemisia absinthium water extract, L. uvarum LUHS245 cultivated in a whey substrate, and blackcurrant juice preparation by-products.

\begin{tabular}{|c|c|c|c|c|c|c|c|c|c|c|c|c|c|c|}
\hline \multicolumn{15}{|c|}{ Inhibition Zones of the Growth of Pathogenic Bacteria by Artemisia absinthium Water Extract, mm } \\
\hline \multicolumn{15}{|c|}{ Pathogenic and Opportunistic Strains } \\
\hline 1 & 2 & 3 & 4 & 5 & 6 & 7 & 8 & 9 & 10 & 11 & 12 & 13 & 14 & 15 \\
\hline- & - & - & - & - & - & - & - & - & - & - & - & - & - & $\begin{array}{c}20.0 \pm \\
4.1\end{array}$ \\
\hline \multicolumn{15}{|c|}{ Inhibition Zones of the Growth of Pathogenic Bacteria by LUHS245, mm } \\
\hline 1 & 2 & 3 & 4 & 5 & 6 & 7 & 8 & 9 & 10 & 11 & 12 & 13 & 14 & 15 \\
\hline $\begin{array}{c}14.1 \pm \\
0.2^{\mathrm{f}}\end{array}$ & $\begin{array}{c}13.3 \pm \\
0.2 \mathrm{e}^{\mathrm{e}}\end{array}$ & $\begin{array}{c}16.0 \pm \\
0.2^{\mathrm{d}}\end{array}$ & $\begin{array}{c}15.3 \pm \\
0.4 \mathrm{e}^{\mathrm{e}}\end{array}$ & $\begin{array}{c}15.3 \pm \\
0.2^{\mathrm{d}}\end{array}$ & $\begin{array}{c}16.3 \\
\pm 0.5 \mathrm{~g}\end{array}$ & $\begin{array}{c}16.1 \pm \\
0.3^{\mathrm{e}}\end{array}$ & $\begin{array}{c}20.0 \pm \\
0.5 \mathrm{e}^{\mathrm{e}}\end{array}$ & $\begin{array}{c}21.5^{ \pm} \\
0.3^{\mathrm{h}}\end{array}$ & - & $\begin{array}{c}13.3 \pm \\
0.2^{\mathrm{b}}\end{array}$ & $\begin{array}{c}14.1 \pm \\
0.3^{c}\end{array}$ & $\begin{array}{c}19.5 \pm \\
0.4^{\mathrm{f}}\end{array}$ & $\begin{array}{c}16.4 \pm \\
0.3^{\mathrm{c}}\end{array}$ & $\begin{array}{c}22.0 \pm \\
0.2^{\mathrm{b}}\end{array}$ \\
\hline \multicolumn{15}{|c|}{ Inhibition Zones of the Growth of Pathogenic Bacteria by Blackcurrant Juice Preparation By-products, mm } \\
\hline- & $\begin{array}{c}10.2 \pm \\
0.2^{\mathrm{a}}\end{array}$ & $\begin{array}{c}16.2 \\
\pm 0.1^{\mathrm{d}}\end{array}$ & $\begin{array}{c}14.6 \pm \\
0.1^{\mathrm{c}}\end{array}$ & $\begin{array}{c}12.2^{ \pm} \\
0.3^{\mathrm{b}}\end{array}$ & $\begin{array}{c}14.0 \pm \\
0.2^{\mathrm{c}}\end{array}$ & $\begin{array}{c}12.5 \pm \\
0.1^{\mathrm{b}}\end{array}$ & $\begin{array}{c}14.3^{ \pm} \\
0.3^{\mathrm{c}}\end{array}$ & $\begin{array}{c}21.4 \pm \\
0.2^{\mathrm{h}}\end{array}$ & $\begin{array}{c}20.1 \pm \\
0.1 \mathrm{~g}\end{array}$ & - & $\begin{array}{c}10.3^{ \pm} \\
0.2^{\mathrm{a}}\end{array}$ & $\begin{array}{c}17.0 \pm \\
0.3^{\mathrm{e}}\end{array}$ & $\begin{array}{c}18.1 \pm \\
0.4^{\mathrm{f}}\end{array}$ & $\begin{array}{c}30.7 \pm \\
0.5^{\mathrm{i}}\end{array}$ \\
\hline
\end{tabular}

Data expressed as mean values $(n=3) \pm \mathrm{SD}$ (standard deviation). ${ }^{\mathrm{a}-\mathrm{i}}$ Mean values with different letters are significantly different $(p \leq 0.05) .1-$ Klebsiella pneumoniae; 2 -Salmonella enterica 24 SPn06; 3-Pseudomonas aeruginosa 17-331; 4-Acinetobacter baumanni 17-380; 5-Proteus mirabilis; 6-Methicillin-resistant Staphylococcus aureus M87fox; 7—Enterococcus faecalis 86; 8-Enterococcus faecium 103; 9-Bacillus cereus 18 01; 10—Streptococcus mutans; 11-Enterobacter cloacae; 12—Citrobacter freundii; 13—Staphylococcus epidermidis; 14-Staphylococcus haemolyticus; 15-Pasteurella multocida.

Table 2. Antimicrobial activities of the Artemisia absinthium EO (concentration $0.1 \%$ ) and Artemisia absinthium water extract (concentrations $10 \%, 20 \%, 30 \%$ ) against pathogenic opportunistic microorganisms in liquid medium (+ indicated pathogen growth; - indicated that pathogen growth was not observed).

\begin{tabular}{|c|c|c|c|c|c|c|c|c|c|c|c|c|c|c|c|}
\hline & \multicolumn{15}{|c|}{ Pathogenic and Opportunistic Strains } \\
\hline & 1 & 2 & 3 & 4 & 5 & 6 & 7 & 8 & 9 & 10 & 11 & 12 & 13 & 14 & 15 \\
\hline A EO & + & + & + & + & + & - & + & - & - & - & + & + & - & + & - \\
\hline Aex $10 \%$ & + & + & + & + & + & + & + & + & + & + & + & + & + & + & + \\
\hline Aex $20 \%$ & + & + & + & + & + & + & + & + & + & + & + & + & + & + & + \\
\hline Aex $30 \%$ & + & + & + & + & + & + & + & + & + & + & + & + & + & + & + \\
\hline $\begin{array}{c}\text { Pathogen } \\
\text { control }\end{array}$ & + & + & + & + & + & + & + & + & + & + & + & + & + & + & + \\
\hline
\end{tabular}

A-Artemisia absinthium; ex—-water extract; EO-essential oil. 1—Klebsiella pneumoniae; 2—Salmonella enterica 24 SPn06; 3—Pseudomonas aeruginosa 17-331; 4-Acinetobacter baumanni 17-380; 5-Proteus mirabilis; 6-Methicillin-resistant Staphylococcus aureus M87fox; 7-Enterococcus faecalis 86; 8-Enterococcus faecium 103; 9-Bacillus cereus 18 01; 10-Streptococcus mutans; 11-Enterobacter cloacae; 12—Citrobacter freundii; 13-Staphylococcus epidermidis; 14-Staphylococcus haemolyticus; 15-Pasteurella multocida. 
Natural plant ingredients are usually characterized as less toxic compared to synthetic ones [30]. Nowaday, EOs, as potential alternatives to synthetic antimicrobials, have become very popular [31]. It was published that terpenes are predominant compounds of the Artemisia absinthium EO [32] and trans sabinyl acetate is a predominant compound in the A. absinthium EO [32]. The lipophilicity of monoterpenes and sesquiterpenes were indicated as the main antimicrobial mechanism of action of the A. absinthium [33]. This characteristic leads to diffusion through microorganism membranes and inhibition of the synthesis processes in bacterial cells [34]. Earlier reports suggested that A. absinthium possesses antibacterial properties $[35,36]$. Also, it was published that the extracts inhibit pathogenic bacteria, but not LAB $[37,38]$.

However, in our study, it was established that the Artemisia absinthium water extract inhibits the growth of Pasteurella multocida (inhibition zone $20.0 \pm 4.1 \mathrm{~mm}$ ), as well as EO (concentration of EO $0.1 \%$ ) inhibited Methicillin-resistant Staphylococcus aureus M87fox, Enterococcus faecium 103, Bacillus cereus 18 01, Staphylococcus epidermidis, and Pasteurella multocida, Table 2; Table 3). According to the obtained results, EO, as a higher antimicrobial activity component, in comparison with Artemisia absinthium water extract, was selected for nutraceuticals preparation.

The second layer of the nutraceuticals was prepared by using lyophilised in a whey media LUHS245 strain. LUHS245 strain showed antimicrobial activities against most of the tested pathogenic opportunistic strains (except Streptococcus mutans), and the highest inhibition zones against Enterococcus faecium 103, Bacillus cereus 18 01, Staphylococcus epidermis, and Pasteurella multocida were found (20.0 \pm $0.5,21.5 \pm 0.3,19.5 \pm 0.4$, and $22.0 \pm 0.2 \mathrm{~mm}$, respectively). Lactic acid bacteria are relevant for many aspects of health $[39,40]$. These bacteria are popular due to the several characteristics related to human/animal health [41]. LAB properties to inhibit pathogens in most of the cases are associated with the production of many metabolites because neutralization of the supernatant reduces antimicrobial properties, and this indicates that the most important factor remains low acidity of the fermentable substrate [42]. Natural antimicrobial agents are of great interest for applications in food, as well as the health industry [43]. LAB have a GRAS (Generally Recognized as Safe) status [44] and from this point of view, are meeting consumer preferences. The third layer of nutraceuticals was prepared by using blackcurrant juice preparation BY, and their antimicrobial activity is shown in Table 2. Blackcurrant juice preparation BY inhibited most of the tested pathogenic strains (except Klebsiella pneumoniae and Enterobacter (loacae), and the highest inhibition zones against Pasteurella multocida and Bacillus cereus 18 01 were found ( $30.7 \pm 0.5$ and $21.4 \pm 0.2 \mathrm{~mm}$, respectively). Blackcurrants are the richest sources of polyphenols of the berry group [45] and they reduce oxidative stress [46], which is a proinflammatory factor that plays a key role in the genesis of many serious diseases, including the civilizational ones, like circulatory diseases, tumors, or diabetes [47]. Bioactive phytocompounds are extra-nutritional constituents that typically occur in small quantities in foods [48], they vary widely in chemical structure and function, and have antioxidant, antiproliferative, antimicrobial, anti-diabetic, estrogenic, acetyl cholinesterase, anti-inflammatory activities, etc. [49,50]. Blackcurrants anthocyanins are one type of flavonoid phytopigments, which showed potential health benefits $[51,52]$. The localization of flavonoids/anthocyanins and their interaction with cell membranes plays an important role in membrane-mediated signaling cascades and influences anti-tumor [53,54], antimicrobial [55], and antioxidant $[56,57]$ properties. 
Table 3. Lactobacillus uvarum LUHS245 count in whey enriched with different quantities of glucose, yeast extract, and saccharose.

\begin{tabular}{|c|c|c|c|c|}
\hline & & \multicolumn{3}{|c|}{ Lactobacillus uvarum LUHS245 } \\
\hline \multicolumn{2}{|c|}{ Sugars } & \multicolumn{3}{|c|}{ Incubation, $\mathrm{h}$} \\
\hline & & $12 \mathrm{~h}$ & $24 \mathrm{~h}$ & $48 \mathrm{~h}$ \\
\hline & & \multicolumn{3}{|c|}{ Lactic Acid Bacteria Count, $\log _{10}$ CFU mL $\mathrm{mL}^{-1}$} \\
\hline & & $6.28 \pm 0.16^{\mathrm{a}}$ & $5.34 \pm 0.14^{\mathrm{a}}$ & $4.29 \pm 0.14^{\mathrm{a}}$ \\
\hline \multirow{10}{*}{ Glucose } & 0.5 & $6.98 \pm 0.09^{c}$ & $6.91 \pm 0.12^{b, c}$ & $6.92 \pm 0.11^{d}$ \\
\hline & 1.0 & $6.39 \pm 0.11^{\mathrm{a}, \mathrm{b}}$ & $6.73 \pm 0.14 b, c$ & $7.06 \pm 0.12^{e}$ \\
\hline & 1.5 & $6.42 \pm 0.12^{a, b}$ & $6.40 \pm 0.16^{b}$ & $6.35 \pm 0.14^{b}$ \\
\hline & 2.0 & $6.41 \pm 0.14^{\mathrm{a}, \mathrm{b}}$ & $6.75 \pm 0.12 b, c$ & $7.12 \pm 0.09$ \\
\hline & 2.5 & $6.20 \pm 0.12^{\mathrm{a}}$ & $7.40 \pm 0.11^{\mathrm{d}}$ & $7.21 \pm 0.13^{\mathrm{e}}$ \\
\hline & 3.0 & $6.83 \pm 0.11^{c}$ & $6.63 \pm 0.12 b, c$ & $6.60 \pm 0.14^{c}$ \\
\hline & 3.5 & $6.20 \pm 0.12^{\mathrm{a}}$ & $6.52 \pm 0.13^{b}$ & $6.69 \pm 0.10^{c}$ \\
\hline & 4.0 & $6.46 \pm 0.12^{\mathrm{a}, \mathrm{b}}$ & $6.61 \pm 0.10 \mathrm{~b}, \mathrm{c}$ & $6.80 \pm 0.14^{c}$ \\
\hline & 4.5 & $7.22 \pm 0.15^{\mathrm{d}}$ & $6.52 \pm 0.14^{b}$ & $6.45 \pm 0.11^{b}$ \\
\hline & 5.0 & $6.34 \pm 0.12^{a}$ & $6.54 \pm 0.12^{b}$ & $6.65 \pm 0.09^{c}$ \\
\hline \multirow{10}{*}{ Yeast Extract } & 0.5 & $7.23 \pm 0.14^{b}$ & $6.63 \pm 0.11^{b}$ & $7.21 \pm 0.10^{d}$ \\
\hline & 1.0 & $7.28 \pm 0.13^{b}$ & $7.22 \pm 0.12^{c}$ & $6.56 \pm 0.12^{b}$ \\
\hline & 1.5 & $7.30 \pm 0.13^{b}$ & $7.69 \pm 0.13^{d}$ & $7.08 \pm 0.11^{c}$ \\
\hline & 2.0 & $7.53 \pm 0.15^{c}$ & $8.11 \pm 0.14^{d}$ & $7.01 \pm 0.14^{c}$ \\
\hline & 2.5 & $7.54 \pm 0.14^{c}$ & $7.69 \pm 0.12^{d}$ & $7.30 \pm 0.10^{e}$ \\
\hline & 3.0 & $7.83 \pm 0.18^{d}$ & $7.85 \pm 0.10^{\mathrm{d}}$ & $7.73 \pm 0.10^{f}$ \\
\hline & 3.5 & $7.90 \pm 0.13^{d}$ & $7.93 \pm 0.14^{d}$ & $7.85 \pm 0.10^{f}$ \\
\hline & 4.0 & $7.94 \pm 0.12^{\mathrm{d}}$ & $7.92 \pm 0.17^{\mathrm{d}}$ & $7.90 \pm 0.11^{f}$ \\
\hline & 4.5 & $7.92 \pm 0.13^{d}$ & $7.94 \pm 0.12^{d}$ & $7.85 \pm 0.12^{f}$ \\
\hline & 5.0 & $7.90 \pm 0.14^{\mathrm{d}}$ & $8.06 \pm 0.14^{d}$ & $7.84 \pm 0.11^{f}$ \\
\hline \multirow{10}{*}{ Saccharose } & 0.5 & $6.82 \pm 0.10^{f}$ & $7.83 \pm 0.12^{c}$ & $8.21 \pm 0.13^{c}$ \\
\hline & 1.0 & $6.19 \pm 0.11^{\mathrm{e}}$ & $7.84 \pm 0.11^{c}$ & $7.84 \pm 0.12^{b}$ \\
\hline & 1.5 & $6.09 \pm 0.12^{d}$ & $7.71 \pm 0.13^{c}$ & $7.90 \pm 0.10^{b}$ \\
\hline & 2.0 & $6.08 \pm 0.14^{d}$ & $7.75 \pm 0.14^{c}$ & $7.81 \pm 0.14^{b}$ \\
\hline & 2.5 & $6.07 \pm 0.10^{d}$ & $7.76 \pm 0.12^{c}$ & $7.94 \pm 0.12^{b}$ \\
\hline & 3.0 & $5.60 \pm 0.15^{c}$ & $5.11 \pm 0.10^{\mathrm{a}}$ & $7.51 \pm 0.10^{a}$ \\
\hline & 3.5 & $5.41 \pm 0.13^{b}$ & $5.52 \pm 0.12^{b}$ & $7.49 \pm 0.13^{a}$ \\
\hline & 4.0 & $5.10 \pm 0.12^{a}$ & $5.10 \pm 0.10^{\mathrm{a}}$ & $7.45 \pm 0.14^{\mathrm{a}}$ \\
\hline & 4.5 & $5.13 \pm 0.14^{\mathrm{a}}$ & $5.11 \pm 0.11^{\mathrm{a}}$ & $7.42 \pm 0.11^{a}$ \\
\hline & 5.0 & $5.11 \pm 0.10^{a}$ & $5.39 \pm 0.13^{b}$ & $7.40 \pm 0.09^{a}$ \\
\hline
\end{tabular}

Values are mean \pm SD of three replicate analyses $(n=3)$. ${ }^{\text {a-f }}$ Mean values within a row (comparison of the different LAB count: within the same LAB, at the different sugars' concentrations. Samples enriched with glucose and yeast extract were compared with control whey samples; samples enriched with saccharose were compared between each other) with different letters are significantly different.

\subsection{Grown and Stabilization of the Lactobacillus uvarum LUHS245 Strain in Dairy Production By-Products Media}

Lactic acid bacteria growth after 12, 24, and $48 \mathrm{~h}$ of cultivation in whey (WHE) is presented in Table 3. After $12 \mathrm{~h}$ of incubation, the highest count of LAB was found in WHE with $4.0 \%$ of the yeast extract $(\mathrm{Y})\left(\sim 7.9 \log _{10} \mathrm{CFU} \mathrm{mL} \mathrm{m}^{-1}\right)$. After $24 \mathrm{~h}$ of incubation, the LAB count in the non-enriched WHE was reduced by $15.0 \%$. Opposite tendencies were found in most of the WHE with glucose (GLU), Y, and saccharose (SA), and in many cases, the additives had a positive influence on the LAB growth. The highest LAB count was found in WHE with $2.0 \%$ of the $\mathrm{Y}\left(8.11 \pm 0.14 \log _{10} \mathrm{CFU} \mathrm{mL} \mathrm{m}^{-1}\right)$. After $48 \mathrm{~h}$ of incubation, the LAB count was the same or decreased, except in samples enriched with $\mathrm{SA}$, and the highest LAB count was found in WHE with $0.5 \%$ of SA $\left(8.11 \pm 0.13 \log _{10} \mathrm{CFU} \mathrm{mL}{ }^{-1}\right)$. The LAB count was significantly influenced by the additives and their quantity, as well as fermentation time $(p \leq 0.0001)$, and the interaction of the analysed factors was significant $(p \leq 0.0001)$. The optimal 
quantities of the additives were $2.5 \%$ of GLU, $2.0 \%$ of $Y$, and $0.5 \%$ of SA. The results of the LAB growth in WHE with the optimum concentration of selected additives are presented in Figure 1. The optimal time for LUHS245 incubation in the WHE with 2.5\% GLU, 2.0\% Y, and 0.5\% SA is $28 \mathrm{~h}$. The highest LAB count in WHE with $2.0 \%$ of $Y$ was observed after $36 \mathrm{~h}$ of incubation. The addition of GLU and SA had a lower influence on the growth of LAB, compared with the addition of Y. LUHS245 strain was incubated in the WHE with 2.5\% GLU, 2.0\% Y, and 0.5\% SA for $28 \mathrm{~h}$ (optimal incubation time) and lyophilised. After lyophilisation, a viable LAB count in the obtained powder was $8.90 \pm 0.12 \log _{10}$ CFU g ${ }^{-1}$.

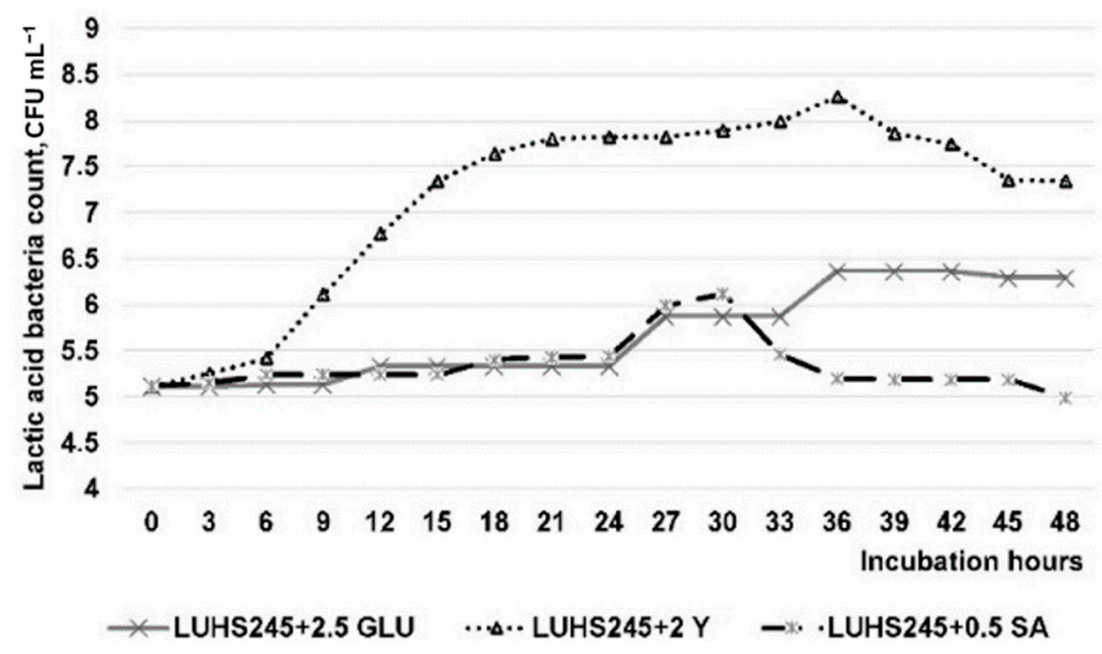

Figure 1. Lactobacillus uvarum LUHS245 biomass growth in dairy by-products media enriched with the optimum concentration of selected additives (LUHS245+2.5 GLU-whey enriched with $2.5 \%$ glucose and fermented with LUHS245; LUHS245+2 YE-whey enriched with $2.0 \%$ yeast extract and fermented with LUHS245; LUHS245+0.5 SACC—-whey enriched with $0.5 \%$ sucrose and fermented with LUHS245).

The uses of technologically functionalized (e.g., dehydrated) starter cultures is more attractive, due to higher technological microorganisms survival and viability under environmental conditions [58]. Viability of LAB increasing for convenient industrial uses can be performed in a sustainable manner. From an environmental, as well as economical point of view, public awareness for food waste and by-products recycling has recently increased, and the dairy industry generates huge amounts of by-products $[59,60]$. Also, LAB biomass preparation by using by-products as nutrient media can lead to a profitable process [61]. Finally, whey is perspective sustainable media for LAB cultivation, as well as dehydratation.

Lyophilisation is the most popular process used to preserve LAB because of its ability to protect from spoilage, as well as its long viability during storage [62,63]. During freezing, bacterial cells are exposed to mechanical stress because of intra- and extra-cellular ice crystal formation and increased osmotic pressure caused by solutes in the remaining unfrozen fraction. This process can lead to the destruction of bacterial membranes and cause harmful damage [64]. Moreover, during lyophilisation, the removal of water by sublimation additionally increases osmotic pressure and can be harmful for membranes and surface proteins [65]. For this reason, cryprotectants are usually added to maintain the viability of microorganisms [64]. Different polymers, sugars, milk, honey, polyols, and amino acids have been tested for their protective effect during lyophilisation [64-66]. Disaccharides, such as maltose, sucrose, and trehalose, are able to induce shrinkage of the cells by osmosis-derived dehydration before freezing, thereby reducing intracellular ice formation [64]. Compounds mixing with different protective mechanisms can have a positive influence on the higher protection of microorganisms during freezing, as well as drying compared with single-component application, due to components' synergic protective effects [64]. Skim milk, containing a mixture of lactoalbumine and casein, as well as saccharides, is a selected cryoprotectant for many LAB due to its ability to prevent cellular damage by 
stabilizing the cell membrane and providing a protein-protective coating for the cells [67]. Moreover, different sugars have high levels of protection of LAB during freeze-drying, due to their ability to replace structural water in membranes after dehydration [68]. It was reported that skim milk powder with lactose or saccharide contained the best cryoprotectans for lactobacilli [67]. For instance, L. lactis CIDCA 8221 lyophilised using milk and sucrose as a cryoprotective medium had a high survival rate and recovery ability [69]. Different additives can improve the viability of LAB in different matrices, as well as dehydratation processes, and increases the stability of strains, thus alleviating production on an industrial scale.

\subsection{The Total Phenolic Compounds Content and Radical Scavenging Activity of Nutraceuticals}

The total phenolic compounds (TPC) content and antioxidant activity of the different layers, as well as whole nutraceutical, are given in Table 4. When comparing Artemisia absinthium EO+agar $(\mathrm{Aex}+\mathrm{Ag})$ and Artemisia absinthium +gelatin $(\mathrm{Aex}+\mathrm{G})$ layers, higher TPC content and antioxidant activity by the (Aex+G) layer was found (by 5.1 and $14.6 \%$ higher, respectively). Different tendencies of the second layer antioxidant properties were obtained, as a higher TPC content of the layer prepared with gelatin was found (by $4.8 \%$ higher), however higher antioxidant activity of the layer prepared with agar was established (by $7.2 \%$ higher). In comparison to whole nutraceutical formulations, higher TPC content was shown by products prepared with gelatin (by $2.1 \%$ higher), however antioxidant activity of the gelatin and agar prepared nutraceuticals was similar (with gelatin prepared, it was $75.15 \pm 3.9 \%$ and with agar prepared, $81.96 \pm 4.5 \%$ ). Significant influence of the gelatin/agar uses on the antioxidant properties of the nutraceuticals was not established.

Free radicals are very reactive in biological systems and an overproduction can lead to various life threatening disorders like atherosclerosis, inflammatory diseases, and cancer [69]. A. absinthium extract possesses antioxidant and free radical scavenging activities in vitro, as well as showing cytotoxic and antitumor activity against different malignancies [69]. Finally, A. absinthium extracts can be novel active drug compounds, as they have antiproliferative, antioxidant, and radical scavenging properties, however additional studies need to be undertaken to carry out the in vivo pharmacological experimentation of this plant [22]. Antioxidants, molecules with a radical scavenging capacity, are considered to exercise a defensive consequence against free radical injury and these molecular components may prevent many chronic diseases like cancer, hepatitis, asthma, atherosclerosis, arthritis, heart disease, and diabetes [70,71]. Currently, many synthetic antioxidants are also used, however these antioxidants have been thought to damage the liver and cause cancer [72]. Due to side effects and toxicity to health, their utilization is restricted [73]. The consumption of plant based additives as antioxidants increases day by day [72]. Plant based antioxidant demand continues to increase in the market, as they are used in food, cosmetic, and pharmaceutical industries to replace synthetic antioxidants. For this reason, plant based by-products can be a valuable source for these substances. Among natural antioxidants, phenolic substances have been of special interest because they are found extensively in plants [72]. Natural products containing phenolic substances have antioxidant potential, mostly because of their redox ability, which enables them to behave as hydrogen donors, single oxygen quenchers, and reducing agents as well as they have the potential to chelate metals [72]. The phenolic substances have taken part in body cell protection from harm by $\mathrm{H}_{2} \mathrm{O}_{2}$, lipid peroxide, unsaturated fatty acid, neutralizing, and absorbing free radicals [74]. However, it is not just plants based antioxidants that are promising for nutraceuticals formulations, the antioxidant properties of LAB were also published [75]. Finally, compositions were developed from different origins of antioxidant properties, showing that compounds can be very attractive for nutraceuticals formulations, as well as can lead to dose reducing and other activities, such as antimicrobial, increasing. 
Table 4. Nutraceuticals colour coordinates (NBS), texture (mJ), total phenolic compounds content (mg $100 \mathrm{~g}^{-1}$ d.m.), antioxidant activity (\%), and overall acceptability (from 140 - extremely like to 0 - extremely dislike).

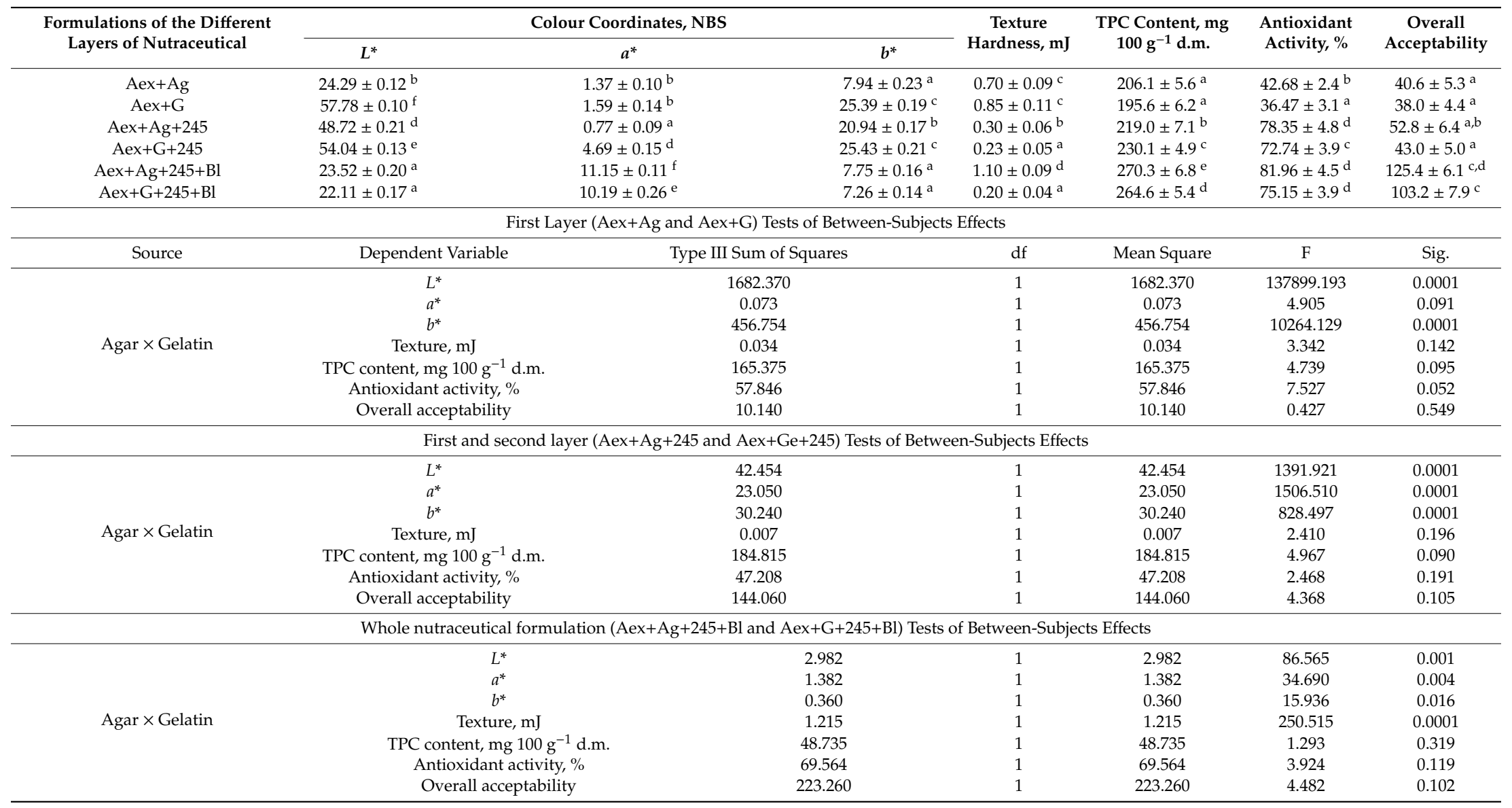

Aex-Artemisia absinthium essential oil; Ag-agar; G—gelatin; 245—Lactobacillus uvarum LUHS245 strains cultivated in dairy by-products; Bl—blackcurrant juice preparation by-products; TPC—-total phenolic compounds content; $L^{*}$ - lightness; $a^{*}$-redness; $b^{*}$ - yellowness. Data expressed as means $(n=3) \pm \mathrm{SD}$; SD - standard deviation. ${ }^{\mathrm{a}-\mathrm{f}}$ Mean values with different letters are significantly different $(p \leq 0.05)$ 


\subsection{Nutraceuticals Colour Coordinates, Texture, and Overall Acceptability}

Nutraceuticals contain different biologically and chemically active compounds. Various processes are applied for nutraceutical ingredients technological functionalization. In this study, all the compounds were analysed in accordance with their antimicrobial properties, however especially plant compounds can possess antioxidant properties as well. However, for the product's success in the market, it is not enough to provide only the desirable functional properties; colour, texture, and its related overall acceptability are also very important. Nutraceuticals colour coordinates, texture, and overall acceptability are shown in Table 4. When comparing Artemisia absinthium EO mmobilized in agar and gelatin, gelatin increased the lightness and yellowness of the first layer (by 58.0 and $68.7 \%$, respectively), however agar or gelatin selection was not significant on the redness coordinates. When comparing the colour coordinates of the second layer, in all the cases, the layer prepared with gelatin showed higher lightness (by $9.8 \%$ higher), redness (by $83.6 \%$ higher), and yellowness (by $17.7 \%$ higher). Gelatin or agar selection for the outer layer preparation was not significant on the lightness and yellowness coordinates, however higher redness by using agar was found (by $8.6 \%$ higher).

When comparing the hardness of the texture, significant differences of the first layer texture hardness were not established, however harder texture of the second and outer layers by using agar was found (by $23.3 \%$ and $81.8 \%$, respectively, higher). When comparing the overall acceptability of the separate layers, as well as whole formulation, it can be stated that the blackcurrant juice preparation by-products are very promising antimicrobial ingredients that are acceptable for consumers and can mask other ingredients for which acceptability is not very high. Between colour coordinates (lightness, redness, yellowness) and overall acceptability of the prepared nutraceuticals, negative moderate $(r=-0.6632)$, positive very strong $(r=-0.9001)$, and negative moderate $(r=-0.6514)$ correlations were found. When comparing whole nutraceuticals formulation prepared with agar and gelatin, higher overall acceptability of the nutraceuticals prepared with agar was established (by 17.7\% higher), however for between nutraceuticals texture and overall acceptability, a very low positive correlation $(r=0.2271)$ was established.

\section{Conclusions}

It can be summarized that antimicrobial and antioxidant properties showing nutraceuticals formulation in chewing tablets form, based on Artemisia absinthium EO (concentration $\leq 0.1$ inhibited methicillin-resistant Staphylococcus aureus M87fox, Enterococcus faecium 103, Bacillus cereus 1801 , Streptococcus mutans, Staphylococcus epidermidis, and Pasteurella multocida), Lactobacillus uvarum LUHS245 encapsulated in a whey media (inhibited 14 from the 15 tested pathogenic strains), and blackcurrant juice preparation by-products (inhibited 13 from the 15 tested pathogenic strains) can be prepared in a sustainable manner. The best formulation consists of the Artemisia absinthium EO, Lactobacillus uvarum LUHS245 encapsulated in a whey media, and blackcurrant juice preparation by-products immobilized in agar as this formulation showed higher TPC content (by 2.1\% higher), as well as higher overall acceptability (by $17.7 \%$ higher), compared with the formulation prepared with gelatin. Finally, compositions were developed from different origin antioxidant properties, showing that compounds can be very attractive for nutraceuticals formulations, as well as can lead to the dose reducing and other activities increasing, e.g. antimicrobial activity. Further experiments are planned to evaluate the antimicrobial activities of Artemisia absinthium extracts and LUHS245 strain against non-pathogenic bacterial strains with the aim to evaluate their influence on normal microbiota.

Author Contributions: Conceptualization, E.B.; methodology, E.B., V.L., V.S. and P.Z.; software, E.Z.; validation, I.V., G.P., L.P., G.R., T.K., L.D. and P.V.; formal analysis, I.V., G.P., L.P., G.R., T.K., L.D. and P.V.; investigation, A.S. and M.R.; data curation, E.B., V.L., V.S. and P.Z.; writing-original draft preparation E.B., V.L., V.S. and P.Z.; writing-review and editing, E.B., V.L., V.S., P.Z., A.S. and E.Z.; visualization, V.S., P.Z. and V.L.; supervision, E.B.; project administration, E.B. All authors have read and agreed to the published version of the manuscript.

Funding: Part of this research was supported by the Lithuanian University of Health Sciences Science Foundation (project No. Nr. 0202/010302). 
Acknowledgments: This research was supported by the COST project "Sourdough biotechnology network towards novel, healthier and sustainable food and bioprocesses" (SOURDOmICS) COST Action (No. CA18101).

Conflicts of Interest: The authors declare no conflict of interest.

\section{References}

1. Nutraceuticals -Market Demand, Growth, Opportunities and Analysis of Top Key Player Forecast to 2026-Investor Opinion. Available online: https://investoropinion.co.uk/nutraceuticals-market-demandgrowth-opportunities-and-analysis-of-top-key-player-forecast-to-2026/ (accessed on 27 December 2019).

2. Mirabella, N.; Castellani, V.; Sala, S. Current options for the valorization of food manufacturing waste: A review Current options for the valorization of food manufacturing waste: A review. J. Clean. Prod. 2013, 65, 28-41. [CrossRef]

3. Daliu, P.; Santini, A.; Novellino, E. From pharmaceuticals to nutraceuticals: Bridging disease prevention and management. Exp. Rev. Clin. Pharmacol. 2019, 12,1-7. [CrossRef] [PubMed]

4. Durazzo, A.; Lucarini, M.; Novellino, E.; Daliu, P.; Santini, A. Fruit-based juices: Focus on antioxidant properties-Study approach and update. Phytother. Res. 2019, 33, 1754-1769. [CrossRef]

5. Daliu, P.; Santini, A.; Novellino, E. A decade of nutraceutical patents: Where are we now in 2018? Exp. Opin. Ther. Pat. 2018, 28, 875-882. [CrossRef]

6. Santini, A.; Cammarata, S.M.; Capone, G.; Ianaro, A.; Tenore, G.C.; Pani, L.; Novellino, E. Nutraceuticals: Opening the debate for a regulatory framework. Br. J. Clin. Pharmacol. 2018, 84, 659-672. [CrossRef] [PubMed]

7. Abenavoli, L.; Izzo, A.A.; Milić, N.; Cicala, C.; Santini, A.; Capasso, R. Milk thistle (Silybum marianum): A concise overview on its chemistry, pharmacological, and nutraceutical uses in liver diseases. Phytother. Res. 2018, 32, 2202-2213. [CrossRef] [PubMed]

8. Santini, A.; Novellino, E. To Nutraceuticals and Back: Rethinking a Concept. Foods 2017, 6, 74. [CrossRef] [PubMed]

9. Prazeres, A.R.; Carvalho, F.; Rivas, J. Cheese whey management: A review. J. Environ. Manag. 2012, 110, 48-68. [CrossRef]

10. Baldasso, C.; Barros, T.C.; Tessaro, I.C. Concentration and purification of whey proteins by ultrafiltration. Desalination 2011, 278, 381-386. [CrossRef]

11. Bosco, F.; Carletto, R.A.; Marmo, L. An Integrated Cheese Whey Valorization Process. Chem. Eng. Trans. 2018, 64, 379-384.

12. Díaz-Vergara, L.; Pereyra, C.M.; Montenegro, M.; Pena, G.A.; Aminahuel, C.A.; Cavaglieri, L.R. Encapsulated whey-native yeast Kluyveromyces marxianus as a feed additive for animal production. Food Addit. Contam. Part A Chem. Anal. Control Exp. Risk Assess. 2017, 34, 750-759. [CrossRef] [PubMed]

13. Eckert, C.; Agnol, W.D.; Dallé, D.; Serpa, V.G.; Maciel, M.J.; Lehn, D.N.; Volken de Souza, C.F. Development of alginate-pectin microparticles with dairy whey using vibration technology: Effects of matrix composition on the protection of Lactobacillus spp. from adverse conditions. Food Res. Int. 2018, 113, 65-73. [CrossRef] [PubMed]

14. Park, K.M.; Yoon, S.-G.; Choi, T.-H.; Kim, H.J.; Park, K.J.; Koo, M. The Bactericidal Effect of a Combination of Food-Grade Compounds and their Application as Alternative Antibacterial Agents for Food Contact Surfaces. Foods 2020, 9, 59. [CrossRef] [PubMed]

15. Verardo, V.; Gómez-Caravaca, A.M.; Tabanelli, G. Bioactive Components in Fermented Foods and Food By-Products. Foods 2020, 9, 153. [CrossRef]

16. Seeram, N.P. Berry fruits for cancer prevention: Current status and future prospects. J. Agric. Food Chem. 2008, 56, 630-635. [CrossRef]

17. Szajdek, A.; Borowska, E.J. Bioactive Compounds and Health-Promoting Properties of Berry Fruits: A Review. Plant Foods Hum. Nutr. 2008, 63, 147-156. [CrossRef]

18. Subash, S.; Essa, M.M.; Al-Adawi, S.; Memon, M.A.; Manivasagam, T.; Akbar, M. Neuroprotective effects of berry fruits on neurodegenerative diseases. Neural Regen. Res. 2014, 9, 1557-1566.

19. Paredes-López, O.; Cervantes-Ceja, M.L.; Vigna-Pérez, M.; Hernández-Pérez, T. Berries: Improving Human Health and Healthy Aging, and Promoting Quality Life-A Review. Plant Foods Hum. Nutr. 2010, 65, $299-308$. [CrossRef] 
20. López, F.; Rodríguez-Bencomo, J.J.; Orriols, I.; Pérez-Correa, J.R. Fruit Brandies. In Science and Technology of Fruit Wine Production; Elsevier Inc.: Amsterdam, The Netherlands, 2016; pp. 531-556.

21. Paunović, S.M.; Mašković, P.; Nikolić, M.; Miletić, R. Bioactive compounds and antimicrobial activity of black currant (Ribes nigrum L.) berries and leaves extract obtained by different soil management system. Sci. Hortic. 2017, 222, 69-75. [CrossRef]

22. Lopes-Lutz, D.; Alviano, D.S.; Alviano, C.S.; Kolodziejczyk, P.P. Screening of chemical composition, antimicrobial and antioxidant activities of Artemisia essential oils. Phytochemistry 2008, 69, 1732-1738. [CrossRef]

23. ISO 15214:1998. Microbiology of Food and Animal Feeding Stuffs-Horizontal Method for the Enumeration of Mesophilic Lactic Acid Bacteria-Colony-Count Technique at 30 Degrees C; American National Standards Institute: New York, NY, USA, 2015.

24. Bartkiene, E.; Lele, V.; Sakiene, V.; Zavistanaviciute, P.; Ruzauskas, M.; Bernatoniene, J.; Jakstas, V.; Viskelis, P.; Zadeike, D.; Juodeikiene, G. Improvement of the antimicrobial activity of lactic acid bacteria in combination with berries/fruits and dairy industry by-products. J. Sci. Food Agric. 2019, 99, 3992-4002. [CrossRef] [PubMed]

25. Bartkiene, E.; Lele, V.; Sakiene, V.; Zavistanaviciute, P.; Ruzauskas, M.; Stankevicius, A.; Grigas, J.; Pautienius, A.; Bernatoniene, J.; Jakstas, V.; et al. Fermented, ultrasonicated, and dehydrated bovine colostrum: Changes in antimicrobial properties and immunoglobulin content. J. Dairy Sci. 2020, 103, 1315-1323. [CrossRef] [PubMed]

26. Vaher, M.; Matso, K.; Levandi, T.; Helmja, K.; Kaljurand, M. Phenolic compounds and the antioxidant activity of the bran, flour and whole grain of different wheat varieties. Procedia Chem. 2010, 2, 76-82. [CrossRef]

27. Zhu, J.; Xiong, L.; Yu, B.; Wu, J. Apoptosis Induced by a New Member of Saponin Family Is Mediated through Caspase-8-Dependent Cleavage of Bcl-2. Mol. Pharmacol. 2005, 68, 1831-1838. [CrossRef]

28. ISO Standard 8586. Sensory Analysis-General Guidelines for the Selection, Training and Monitoring of Selected Assessors and Expert Sensory Assessors, 1st ed.; International Organization for Standardization: Geneva, Switzerland, 2012; pp. 1-28.

29. Eriksson, L.; Lif Holgerson, P.; Esberg, A.; Johansson, I. Microbial Complexes and Caries in 17-Year-Olds with and without Streptococcus mutans. J. Dent. Res. 2018, 97, 275-282. [CrossRef]

30. Rizvi, S.A.H.; Ling, S.; Tian, F.; Xie, F.; Zeng, X. Toxicity and enzyme inhibition activities of the essential oil and dominant constituents derived from Artemisia absinthium L. against adult Asian citrus psyllid Diaphorina citri Kuwayama (Hemiptera: Psyllidae). Ind. Crops Prod. 2018, 121, 468-475. [CrossRef]

31. Prakash, B.; Kujur, A.; Yadav, A.; Kumar, A.; Singh, P.P.; Dubey, N.K. Nanoencapsulation: An efficient technology to boost the antimicrobial potential of plant essential oils in food system. Food Control 2018, 89, 1-11. [CrossRef]

32. Judzentiene, A.; Budiene, J.; Gircyte, R.; Masotti, V.; Laffont-Schwob, I.; Laffont, I.; Toxic, S. Activity and Chemical Composition of Lithuanian Wormwood (Artemisia absinthium L.) Essential Oils. Records of Naturals Products. Rec. Nat. Prod. 2012, 6, 180-183.

33. Crevelin, E.J.; Caixeta, S.C.; Dias, H.J.; Groppo, M.; Cunha, W.R.; Martins, C.H.G.; Crotti, A.E.M. Antimicrobial Activity of the Essential Oil of Plectranthus neochilus against Cariogenic Bacteria. Evid. Based Complement. Altern. Med. 2015, 2015, 102317. [CrossRef]

34. Abad, M.J.; Bedoya, L.M.; Apaza, L.; Bermejo, P. The artemisia L. Genus: A review of bioactive essential oils. Molecules 2012, 17, 2542-2566. [CrossRef]

35. Kordali, S.; Kotan, R.; Mavi, A.; Cakir, A.; Ala, A.; Yildirim, A. Determination of the chemical composition and antioxidant activity of the essential oil of Artemisia dracunculus and of the antifungal and antibacterial activities of Turkish Artemisia absinthium, A. dracunculus, Artemisia santonicum, and Artemisia spicig. J. Agric. Food Chem. 2005, 53, 9452-9458. [CrossRef] [PubMed]

36. Moslemi, H.R.; Hoseinzadeh, H.; Badouei, M.A.; Kafshdouzan, K.; Fard, R.M.N. Antimicrobial Activity of Artemisia absinthium Against Surgical Wounds Infected by Staphylococcus aureus in a Rat Model. Indian J. Microbiol. 2012, 52, 601-604. [CrossRef] [PubMed]

37. Chan, C.L.; Gan, R.Y.; Shah, N.P.; Corke, H. Polyphenols from selected dietary spices and medicinal herbs differentially affect common food-borne pathogenic bacteria and lactic acid bacteria. Food Control 2018, 92, 437-443. [CrossRef] 
38. Mohan, A.; Hadi, J.; Gutierrez-Maddox, N.; Li, Y.; Leung, I.K.H.; Gao, Y.; Shu, Q.; Quek, S.-Y. Sensory, Microbiological and Physicochemical Characterisation of Functional Manuka Honey Yogurts Containing Probiotic Lactobacillus reuteri DPC16. Foods 2020, 9, 106. [CrossRef]

39. Sauer, M.; Russmayer, H.; Grabherr, R.; Peterbauer, C.K.; Marx, H. The Efficient Clade: Lactic Acid Bacteria for Industrial Chemical Production. Trends Biotechnol. 2017, 35, 756-769. [CrossRef]

40. Bartkiene, E.; Bartkevics, V.; Mozuriene, E.; Krungleviciute, V.; Novoslavskij, A.; Santini, A.; Rozentale, I.; Juodeikiene, G.; Cizeikiene, D. The impact of lactic acid bacteria with antimicrobial properties on biodegradation of polycyclic aromatic hydrocarbons and biogenic amines in cold smoked pork sausages. Food Control 2017, 71, 285-292. [CrossRef]

41. Porto, M.C.W.; Kuniyoshi, T.M.; Azevedo, P.O.S.; Vitolo, M.; Oliveira, R.P.S. Pediococcus spp.: An important genus of lactic acid bacteria and pediocin producers. Biotechnol. Adv. 2017, 35, 361-374. [CrossRef] [PubMed]

42. Rzepkowska, A.; Zielińska, D.; Ołdak, A.; Kołożyn-Krajewska, D. Safety assessment and antimicrobial properties of the lactic acid bacteria strains isolated from polish raw fermented meat products. Int. J. Food Prop. 2017, 20, 2736-2747. [CrossRef]

43. Nghe, D.; Nguyen, T. Characterization of Antimicrobial Activities of Pediococcus pentosaceus Vtcc-B-601. J. Appl. Pharm. Sci. 2014, 4, 61-64.

44. World Health Organization. Probiotics in Food Health and Nutritional Properties and Guidelines for Evaluation; Food and Agriculture Organization of the United Nation: Rome, Italy, 2011; pp. 1-50.

45. Piatkowska, E.; Kopec, A.; Leszczynska, T. Anthocyanins-their profile, occurrence, and impact on human organism. ZYWNOSC-Nauka Technol. Jakosc. 2011, 4, 24-35. [CrossRef]

46. Chrubasik, C.; Li, G.; Chrubasik, S. The clinical effectiveness of chokeberry: A systematic review. Phytother. Res. PTR 2010, 24, 1107-1114. [CrossRef] [PubMed]

47. Strugala, P.; Dudra, A.; Gabrielska, J. Activity of blackcurrant and chokeberry extracts and two major cyanidin glycosides against lipid membrane oxidation and their binding properties to albumin. Acta Pol. Pharm. 2017, 74, 679-687. [PubMed]

48. Kris-Etherton, P.; Hecker, K.D.; Bonanome, A.; Coval, S.; Binkoski, A.; Hilpert, K.; Griel, A.; Etherton, T. Bioactive compounds in foods: Their role in the prevention of cardiovascular disease and cancer. Am. J. Med. 2002, 113, 71S-88S. [CrossRef]

49. Anhê, F.F.; Desjardins, Y.; Pilon, G.; Dudonné, S.; Genovese, M.I.; Lajolo, F.M.; Marette, A. Polyphenols and type 2 diabetes: A prospective review. PharmaNutrition 2013, 1, 105-114. [CrossRef]

50. Singh, M.; Kaur, M.; Silakari, O. Flavones: An important scaffold for medicinal chemistry. Eur. J. Med. Chem. 2014, 84, 206-239. [CrossRef]

51. Wang, L.-S.; Stoner, G.D. Anthocyanins and their role in cancer prevention. Cancer Lett. 2012, 269, 281-29052. [CrossRef]

52. Tsuchiya, H. Structure-dependent membrane interaction of flavonoids associated with their bioactivity. Food Chem. 2010, 120, 4-1089. [CrossRef]

53. Selvaraj, S.; Krishnaswamy, S.; Devashya, V.; Sethuraman, S.; Krishnan, U.M. Influence of membrane lipid composition on flavonoid-membrane interactions: Implications on their biological activity. Prog Lipid Res. 2015, 58, 1-13. [CrossRef]

54. Strugala, P.; Dudra, A.; Kucharska, A.Z.; Sokół-Lętowska, A.; Wojnicz, D.; Cisowska, A.; Hendrich, A.B. Biological Activity of the Methanol and Water Extracts of the Fruits of Anthocyanin-Rich Plants Grown in South-West Poland. Nat. Prod. Commun. 2015, 10, 474-476. [CrossRef]

55. Arora, A.; Byrem, T.M.; Nair, M.G.; Strasburg, G.M. Modulation of liposomal membrane fluidity by flavonoids and isoflavonoids. Arch. Biochem. Biophys. 2000, 373, 102-109. [CrossRef]

56. Strugała, P.; Dudra, A.; Gabrielska, J. Interaction between mimic lipid membranes and acylated and nonacylated cyanidin and its bioactivity. J. Agric. Food Chem. 2016, 64, 7414-7422. [CrossRef] [PubMed]

57. Kavitake, D.; Kandasamy, S.; Devi, P.B.; Shetty, P.H. Recent developments on encapsulation of lactic acid bacteria as potential starter culture in fermented foods-A review. Food Biosci. 2018, 21, 34-44. [CrossRef]

58. Kosseva, M.R. Management and Processing of Food Wastes. In Comprehensive Biotechnology, 2nd ed.; Elsevier Inc.: Amsterdam, The Netherlands, 2011; Volume 6, pp. 558-593.

59. Kasmi, M.; Hamdi, M.; Trabelsi, I. Processed milk waste recycling via thermal pretreatment and lactic acid bacteria fermentation. Environ. Sci. Pollut. Res. Int. 2017, 24, 13604-13613. [CrossRef] [PubMed] 
60. Breton Toral, A.; Trejo Estrada, S.R.; McDonald, A.G. Lactic Acid Production from Potato Peel Waste, Spent Coffee Grounds and Almond Shells with Undefined Mixed Cultures Isolated from Coffee Mucilage from Coatepec Mexico. Ferment. Technol. 2016, 6, 1-6. [CrossRef]

61. Dimitrellou, D.; Panagiotis, K.; Kourkoutas, Y. Effect of cooling rate, freeze-drying, and storage on survival of free and immobilized Lactobacillus casei ATCC 393. LWT Food Sci. Technol. 2016, 69, 468-473. [CrossRef]

62. Manohar, P.; Ramesh, N. Improved lyophilization conditions for long-term storage of bacteriophages. Sci. Rep. 2019, 9, 1-10. [CrossRef]

63. Bircher, L.; Geirnaert, A.; Hammes, F.; Lacroix, C.; Schwab, C. Effect of cryopreservation and lyophilization on viability and growth of strict anaerobic human gut microbes. Microb. Biotechnol. 2018, 11, 721-733. [CrossRef]

64. Broeckx, G.; Vandenheuvel, D.; Claes, I.J.J.; Lebeer, S.; Kiekens, F. Drying techniques of probiotic bacteria as an important step towards the development of novel pharmabiotics. Int. J. Pharm. 2016, 505, 303-318. [CrossRef]

65. Mendoza, G.M.; Pasteris, S.E.; Otero, M.C.; Nader-Macías, M.E.F. Survival and beneficial properties of lactic acid bacteria from raniculture subjected to freeze-drying and storage. J. Appl. Microbiol. 2014, 116, 157-166. [CrossRef]

66. Chang, L.; Shepherd, D.; Sun, J.; Ouellette, D.; Grant, K.L.; Tang, X.; Pikal, M.J. Mechanism of protein stabilization by sugars during freeze-drying and storage: Native structure preservation, specific interaction, and/or immobilization in a glassy matrix? J. Pharm. Sci. 2005, 94, 1427-1444. [CrossRef]

67. Bolla, P.A.; Serradell, M.; de los, A.; de Urraza, P.J.; De Antoni, G.L. Effect of freeze-drying on viability and in vitro probiotic properties of a mixture of lactic acid bacteria and yeasts isolated from kefir. J. Dairy Res. 2011, 78, 15-22. [CrossRef] [PubMed]

68. Bhat, M.Y.; Gul, M.Z.; Lohamror, L.R.; Qureshi, I.A.; Ghazi, I.A. An in vitro Study of the Antioxidant and Antiproliferative Properties of Artemisia absinthium-A Potent Medicinal Plant. Free Radic. Antioxid. 2018, 8, 160-164.

69. Formagio, A.S.N.; Volobuff, C.R.F.; Santiago, M.; Cardoso, C.A.L.; Vieira, M.D.C.; Pereira, Z.V. Evaluation of antioxidant activity, total flavonoids, tannins and phenolic compounds in Psychotria leaf extracts. Antioxidants 2014, 3, 745-757. [CrossRef] [PubMed]

70. Papuc, C.; Diaconescu, C.; Nicorescu, V. Antioxidant activity of sea buckthorn (Hippophae Rhamnoides) extracts compared with common food additives. Roum. Biotechnol. Lett. 2008, 13, 4049-4053.

71. Amensour, M.; Sendra, E.; Abrini, J.; Pérez-Alvarez, J.A.; Fernández-López, J. Antioxidant activity and total phenolic compounds of myrtle extracts. CYTA J. Food 2010, 8, 95-101. [CrossRef]

72. Moure, A.; Cruz, J.M.; Franco, D.; Manuel Domínguez, J.; Sineiro, J.; Domínguez, H.; Núñez, M.J.; Carlos Parajó, J. Natural antioxidants from residual sources. Food Chem. 2001, 72, 145-171. [CrossRef]

73. Dai, J.; Mumper, R.J. Plant phenolics: Extraction, analysis and their antioxidant and anticancer properties. Molecules 2010, 15, 7313-7352. [CrossRef]

74. Sroka, Z.; Cisowski, W. Hydrogen peroxide scavenging, antioxidant and anti-radical activity of some phenolic acids. Food Chem. Toxicol. 2003, 41, 753-758. [CrossRef]

75. Ding, W.; Wang, L.; Zhang, J.; Ke, W.; Zhou, J.; Zhu, J.; Guo, X.; Long, R. Characterization of antioxidant properties of lactic acid bacteria isolated from spontaneously fermented yak milk in the Tibetan Plateau. J. Funct. Foods 2017, 35, 481-488. [CrossRef]

(C) 2020 by the authors. Licensee MDPI, Basel, Switzerland. This article is an open access article distributed under the terms and conditions of the Creative Commons Attribution (CC BY) license (http://creativecommons.org/licenses/by/4.0/). 